\title{
Electronic Media Studies in Upgrading Learning and Teaching: Effective Strategy Provided by RTM
}

\author{
MOKHTAR MUHAMMAD \\ HALIZA HASAN \\ AEYNEDA ZAIRYN ABDUL JALIL \\ NUR AZIEMAH MOHD AZMAN \\ RAJA PUTRI NADIAH RAJA AHMAD \\ MARDHIYAH MOHAMED ZIN \\ Universiti Teknologi Mara
}

\begin{abstract}
Listening to the radio is one of the mediums of communication that is still popular among Malaysians, no matter the age or gender or economic status. It is the choice of all segments of society as it is relevant to our daily lives. However, most Malaysian listeners still preferred listening to the Top Five private radio stations such as Hot FM, Suria FM and ERA FM as compared to RTM-owned ones. The listeners' perception is the main factor that is closely aligned with the acceptance and popularity of radio stations. This study used the quantitative research method to analyze the factors that contribute to the effectiveness of radio stations provided by Radio Television Malaysia (RTM) among listeners in Klang Valley. It focused on 130 respondents residing around the Klang Valley area. The variables tested in this study include perception, acceptance, radio deejays (DJs), radio content, songs, and promotion. As a result, radio station DJs are the main factor that influences the effectiveness of radio stations provided by RTM. In conclusion, the results from this study will help improve RTM's services and quality to increase the listeners' interest in the radio stations through the identification of the factors that contribute to the effectiveness of radio stations among the listeners in the Klang Valley area.
\end{abstract}

Keyword: Electronic media, teaching and learning, effective strategy, digital, analogue.

\section{INTRODUCTION}

The advancement of technologies in this age has made mass media a priority in the overall development of technology and globalization. Media will always be a part of the society in every field explored. Media can influence the public's understanding of any topic related to it (Shin, 2009). Media can bring many changes to society, as well as a world that is changing every day to focus more on technology. Watching television and listening to the radio has become an important social activity, almost everyone's daily lives.

TVs and radios are mediums that provide information and entertainment to the people in general. Without TVs and radios, the attempts to create an informative human being would not have been possible. Therefore, the role of mass media as a disseminator of information and extensive information is important so that people receive and then think rationally about such information. According to Abdullah and Mawaddah (2011), social behaviour, culture, personality development, whether positive or negative, are sometimes characterized by the media as a channel to obtain information, entertainment, and knowledge. A study by Ahlam et al. (2015) aimed to find the use of social media such as Facebook to reduce stress and enhance job performance. 
There are a variety of Malay-language radio channels that introduce various concepts to attract their audience, whether public or private radio stations. ERA FM and Hot FM is an example of private radio stations that are always competing to become Number One in Malaysia. As a medium to deliver audio information, radios seek to 'lure' their listeners using approaches and concepts that can easily get them hooked. Radio stations provided by RTM use various methods and approaches to deliver information and convey messages with ease so that the number of listeners increases day by day. Communicating in this modern era can increase the interaction with the public, exchange opinions and can also interact face-to-face (Ziad, 2006).

Based on research done by Seksyen Dasar dan Penyelidikan, RTM, (2014, 2015), the audience's perception is the main factor that is closely aligned with the acceptance and popularity of radio stations. Audiences certainly have their impression towards RTM, which mainly published the government's content. Therefore, it is also known as the government's tongue. Until today, the public perception towards radio and TV stations by RTM is still the same. Government's radio is for government information, although the information provided by RTM is still compatible with the latest information. The historical events and RTM radio stations development discussed in this research is important to those who are interested to learn and teach (especially academics) on this topic.

\section{LITERATURE REVIEW}

This study will benefit not only the researcher but also society in general. The findings from this study will be used as a guide for the departments to make improvements so that the radio stations are more relevant and credible as a favourite. Within the communication field, the development of new media has a major impact on the pacification of information to the audience. Radio, as an informer or a radio station, is the body that manages the information using frequencies as a medium to deliver information. Radio is a medium that has a different function and is the most preferred medium of communication. Also, the radio can give the impression to the listeners about what the presenter is trying to convey. Radio is also personal because most listeners listen individually, rather than collectively. Radios play an important role in moving the emotions of listeners using elements such as songs, sound effects and many more. It causes an emotional impact on the audience. Radio is also convenient, which means listeners can listen to the radio wherever they are. A radio is also simple, easy, and mobile, so listeners can listen to the radio wherever they are, for example, in the vehicle, on a mobile phone, and an MP3 player, to name a few. Radios can easily draw the listeners' attention by having programs that appeal to the listeners' interests.

Perception comes from the mind, the heart, and sometimes from the imagination. It is also hypothetical. Therefore, when a person perceives something they see or hear, that thought can either be great or terrible. However, every individual is still entitled to have their perception about a certain issue; may it be good or bad. Different meanings can arise from one's heart and mind or through different associations of their surroundings, and many are easily influenced by the environment in which they are associated with.

Historically, broadcasting in Malaysia has long established itself as an important spatial extension of this nation's historicity. In this day and age, the field of broadcasting is undoubtedly very advanced and vibrant in tandem with technological advancement. The advent of new media with practical and ideological changes of traditional media has impacted social change and subsequently transformed the world communication unification landscape. 
Malaysia was one of the earliest British colonies to operate a radio broadcasting service. However, the British government did not show much interest in radio in its early stage of development (Asiah, 1994). Amateurs electric companies, telecommunication personnel, and radio enthusiasts were among those who started the ball rolling. In $1921 \mathrm{~A}$. L. Birch, the chief electrical engineer of the Johore state government, experimented with a Peto Scott type of wireless set obtained from overseas (Malay Mail, 30 July 1921). In 1923 he formed the Johore Wireless Society, which triggered the formation of nearly one dozen radio societies throughout Malaya. News music and songs from the phonograms were among the first programs broadcast.

The multi-racial nature of the nation's broadcasting system has roots in 1934 when Station ZHJ of Penang began services in four main languages (Mathews, 1973). During the Japanese occupation of Malaya in 1942-1945, the Japanese Military Administration bent on establishing "Die Greater East Asia Co-Prosperity Sphere", fully utilized radio for its political propaganda (Asiah, 1987, p.36). Radio programs were broadcast in various Chinese dialects, as well as in Japanese, Tamil and Malay languages. English was only used in news broadcasts.

When the war ended, the British Military Administration (EMA) re-established control over all radio stations in Malaya, and on April 1, 1946, created a Pan-Malayan Department of Broadcasting known as Radio Malaya, with its headquarters in Singapore (Radio Television Malaysia, undated). Broadcasting was administered by the Broadcasting Department of Malaya but controlled by the Government Information and Printing Office (Asiah, 1984, p. 14).

Broadcasts from the station were reportedly heard throughout the world (New Straits Times, April 1, 1984). In 1973, Radio Malaysia broadcast 475 hours and 25 minutes per week, of which 168 were in Bahasa Malaysia, 100.55 in Chinese, 100 in English, 92.30 in Tamil and 14 in aboriginal languages (Lent, 1978).

Radio Malaysia, the national broadcasting service, is divided into five networks: Ibukota, a special Malay language service for Kuala Lumpur; National in Bahasa Malaysia; Blue, English; Green, Chinese and Red, Tamil. On an average day, Survey Research Malaysia estimated recently, 1, 719, 000 adults listen to the National Network, 97.8 per cent of whom are "Malays. The average numbers for the other language networks are 178, 000 for the English, 778, 000 for the Chinese and 288, 000 for the Tamil (Jack \& Balakrishnan, 1978).

Radio Television Malaysia has as its main purpose, the presentation of government information in a favourable light. Bahasa Malaysia is the preferred language. For example, the main news show on Radio Malaysia is "Berita Perdana" (Prime News), broadcast in Malay and used on all networks (Mohd. Naim, 1974).

Television began in December 1963; a second network was opened in 1969. Network One, carrying Bahasa Malaysia programs, telecasts 57 hours weekly while the second channel, using English, Chinese and Tamil, is on for 27 hours per week. Initially, a very large proportion of the programming was foreign-produced, hut efforts are increasingly made to localize content. For example, in 1973, a 50 per cent surcharge was tacked onto foreign produced TV commercials to encourage the development of local advertisements for the medium (Leader, Vol. 2, No.3, 1973, stated in Lent, 1978). Also, in 1973, the Ministry of Information initiated "Dendang Rakyat", a series of competitions on radio and television to revive interest in traditional Malay music and to offset the invasion of pop music. The competitions are also used to transmit government messages to rural folk and to break down state identities within the nation. Each regional station of RTM handles competitions for a 
certain type of folk music: boria at Penang, ghazal at Johor Bahru, dondang sayang at Malacca, etc. All of the competitions are national development-oriented but appeal chiefly to the Malay ethnic group (Aziz \& Zainie, 1974). The national language is encouraged in all programming; for example, on Television Malaysia, all opening, closing and spot announcements are in that language and Malay subtitles and dubbing are used on TV shows in English, Chinese or Tamil. Of five newscasts on Television Malaysia, two are in Malay; the 9 p.m. one is the most important newscast.

Rediffusion is a government-licensed but privately-owned wire radio service that provides musical and other forms of radio entertainment to hotels, coffee shops, restaurants, factories, hospitals, schools or clubs as well as individual subscribers in the larger towns of Peninsular Malaysia, namely Kuala Lumpur, Petaling Jaya, Ipoh, Georgetown and Butterworth (Anderson, 1984, p.204; Santokh, 1979, p.91). There were 57,742 subscribers in 1982 and about 97 per cent of its listeners were Chinese (Adnan, 1985, p. 165), comprising the young and old alike, housewives, businessmen, skilled workers, young adults and mothers with young families (Audience Research, 1983). Programs produced locally or imported from Hong Kong, and broadcast by Rediffusion are constantly monitored by the Ministry of Information.

An example that requires mentioning is the public's perception of RTM. Despite the station's many attempts to improve its quality and services, it is still unable to attract more viewers and listeners due to the negative impression that has already existed in the society many years before. Unless the viewers and listeners themselves are open to accepting the change, a turn in the public perception is difficult, especially when the government owns the station, and that they decide all activities. In conclusion, perception can affect what is assumed previously. Perception has not been studied in detail. In this regard, it is important to consider the context of the object or event as elements influencing our perception towards the environment.

According to McCombs $(2005,2018)$, the relationship between mass media and audience in Agenda Setting Theory (AST) in which the mass media when displaying a message, the mass media depicts the key elements is becoming a major impression in the minds of viewers. Thus, the priority agenda of the mass media affect the priority on the agenda of the public. Over time, the agenda of the mass media is also considered important in the public agenda.

This theory assumes that the media can influence public opinion if it gives more attention to several issues and reduces attention to other issues. Audiences will know more about the things that are given more attention by the media and will figure out the importance of things in order of importance given by the media. Based on this assumption, the media is considered to have the power to influence the thinking audience to decide the agenda of the matters to be discussed and considered. This situation shows the media agenda influence the public agenda and public agenda also influence the policy agenda. Therefore, we can deduce the mass media have a strong influence on the public agenda but depending on the situation. It can be said that the main assumption of this theory is that an audience member made a conscious choice and aroused to the channel and the content provided.

As we have mentioned earlier, perception is defined as the process by which individuals organize and interpret things. According to Robbins (2001), interpretation of a certain situation or issue is based on the effects of one's senses to give meaning to them. The above interpretation is supported by Thoha (1998), in which it was said that perception is essentially a cognitive process that is normally experienced by everyone to understand the 
information either by sight or hearing. The process of view or perception is the result of a relationship between men and the influence of past experiences or memories, interests, and attitudes. This, in turn, affects a person's behaviour towards the situation or issue, and how their thoughts are communicated. So, perception can also be interpreted as making decisions or delivering thoughts based on the input received from the environment after combining with memories or experiences.

From the above definition, it can be said that there are factors that can affect public perception towards an individual; for example, when they see an object and automatically retained into memory. The object is then interpreted based on personal characteristics, as well as an already existing perception towards the individual (Robbins, 2001). This is in line with the public perception towards their favourite radio station. People can perceive a radio station as uninteresting due to an already existing perception that has been influenced by previous experiences. These perceptions are sometimes accurate; though there are times when they are not. This philosophy of a guided and guarded media has thus far been the working formula for the media to function in a multi-ethnic and multi-religious environment (Kaur \& Shaari, 2006).

Malaysia is expected to fully transition from analogue television (TV) to digital by 2020 said Malaysian Communications and Multimedia Minister, Datuk Seri Ahmad Shabery Cheek (Utusan Malaysia, 7 April 2015). In other words, determination from developing countries led RTM to implement digital technology and analogue shut down in 2015 (Intan \& Juliana, 2016). Thus, RTM must take the initiative to transform implementing digital broadcasting for radio and TV. This transformation should consider the readiness and acceptance of Malaysia, particularly in rural areas.

According to Deputy Director of Broadcasting (Strategic) Datuk Adilah Shek, Radio Television Malaysia (RTM) expects the transition of analogue systems to state-owned station digitals to be completed in 2017. RTM is optimistic that when the process is completed, it will benefit viewers to enjoy better visuals and programs. "RTM digitization cannot be done in a hurry because there are many aspects that need to be emphasized and therefore, we expect the transition to take two years. However, so far, the process has been going smoothly with various preparations underway" (Radio Television Malaysia (RTM), see in The Star, 10 October 2015).

While according to Deputy Minister of Communications and Multimedia Malaysia, Datuk Jailani Johari, The Ministry of Communications and Multimedia is targeting Radio Television Malaysia (RTM) to move to fully digital television broadcasting in 2018. RTM is developing several programs for the transition (Utusan Malaysia, 10 October 2016).

Datuk Jailani Johari also said that Malaysia is now in the process of digitizing the television system which is expected to begin in 2018, RTM started its initial phase of digital broadcasting on 7 Mac 2017 and was launched by Datuk Jailani Johari (Kementerian Komunikasi dan Multimedia Malaysia, 7 March 2017).

Secretary of the Ministry of Communications and Multimedia, Datuk Seri Dr Sharifah Zarah Syed Ahmad, again stressed that The Ministry of Communications and Multimedia is targeting Radio Television Malaysia (RTM) to move to fully digital television broadcasting in 2018. RTM is developing several programs for the transition. "We have had some discussions, and we cannot escape this digitization process because we are everywhere in today's world, that's the world the digital age" (Berita RTM, 2018). 
The transition from analogue to digital is underway, and I'm proud that RTM is ready to move. This digitization project has begun. The Malaysian Communications and Multimedia Minister, Gobind Singh Deo said that he understands that RTM pioneered this project as early as 2004 and soon we will face Analog Switch-Off (ASO), where analogue television broadcasts will be discontinued and will be fully operational in High Definition (HD) and Standard Definition digital broadcasts (SD). We will all be able to enjoy a better quality of television broadcasting that covers more areas than ever before (Kementerian Komunikasi dan Multimedia Malaysia, 2019).

A radio station must operate at its optimum capacity to be highly competitive in its industry. It requires delivering the best programs to the audience. Thus, a radio station must formulate an effective strategy for their programs are to be popular among the listeners. The strategies may involve various factors that back radio programs, such as the program contents, the DJ's, the song choices, and the promotional activities to cast out updates about the programs. Having said all that, it is, therefore, the aim of this study, to investigate, from radio listeners' perspectives, the effectiveness of the strategies employed by RTM's radio stations regarding four factors, namely, DJ's, content, songs, and promotion. This research was conducted to answer the question of what are the levels of effectiveness of radio stations provided by RTM towards their listeners. Consequently, the objectives of this study are (i) to identify the level of perception towards radio stations provided by RTM, (ii) to explore the connections of these factors toward understanding the level of listeners' perception towards RTM Radio Station, and (iii) to discover the factor that imposed the highest influence.

The emergence of the Internet had brought a lot of changes in the mass media landscape. The conventional media had moved to a digital format and formed a media convergence that can attract an audience's interests especially the youths. A new medium that resulted from the combination of Internet and television, namely television portal to assess the levels of gratification of the medium usage among youths. An assessment made by exploring the relationship between the gratification sought (GS) and the gratification obtained (GO) for four measures of gratification, namely the need to obtain information, entertainment, interpersonal utility and also interactivity. There are suggestions to RTM to improve the weaknesses that were identified in the effort to exploit the new media to capture and attract youth audience to expose them with the RTM's programs (Hasrul \& Bahiyah, 2011).

The shift in the form of broadcasting to the internet proves that the internet provides greater satisfaction than other media (Valkenburg \& Soeters, 2001). As a multifunctional medium, it is a combination media like television, books, radio and video games made it more popular and popular among young people and teens. Process the integration between the internet and television has been around for a long time a series of shows and television stations began to develop the site their web (Steven, 2004).

\section{METHODOLOGY}

This study intended to explore the factors that support the media strategies of RTM. Subsequently to explore the connections of these factors toward explaining the perception of RTM Radio Station. The study employed a convenient sampling method where 130 individuals living in the Klang Valley area, who listened to the radio, and are aged 20 and above became the respondents. The study is based on the respondents' opinion on the content of the radio programmes provided by RTM such as Sinar FM and Klasik Nasional. This 
research utilized the survey method using a self-reported questionnaire designed by the researchers. This data collection technique is typically used when the measures are to be reported directly by the respondents (Babbie, 2010). The factors associated with the radio program measured in the study are Perception, Expectation, DJ's Criteria, Radio Content, Songs, and Promotion. Each factor contains nine questions to be evaluated by the respondents (refer to Appendix 1). Questions were developed to capture variables which include information and the habits of respondents when listening to the radio, the respondents' demographics (gender, age, race, level of education, as well as occupation), the perception and acceptance towards RTM radio stations, DJ's criteria, radio program contents, songs selection, and promotions, that contribute to the effectiveness of radio stations. All questions on perception, acceptance, criteria, and promotions measured using a five-point Likert scale, ranging from Strongly Disagree (denoted by ' 1 ') to Strongly Agree (denoted by '5').

A pilot study involving 30 individuals was conducted to ascertain the factors measured are reliable. The degree of reliability is illustrated by a Cronbach's alpha value of at least 0.7 (George \& Mallery, 2010) as it demonstrated that the items are reliable in measuring the factors. The result (see Table 1) from the pilot study demonstrated Cronbach's alpha value of more than 0.7 for all factors; hence, all items are usable for the actual survey.

Table 1: Cronbach's Alpha Value for each Factor

\begin{tabular}{cc}
\hline Factors & Cronbach's Alpha \\
\hline Perception & .743 \\
Expectation & .869 \\
DJ's Criteria & .890 \\
Radio Content & .826 \\
Songs & .810 \\
Promotion & .908 \\
\hline
\end{tabular}

This study is designed as a quantitative study because it uses methods that 'captures details of the media world" and these findings are presented in numerical analysis (Neuman, 2011). Other questions in the questionnaire are used to characterize the demographic factors of the respondents. These factors are used in the analyses for identifying differences in the opinion across demographic factors. Data were analyzed by utilizing the descriptive and inferential statistics, using IBM Statistical Packages for Social Science (SPSS).

\section{RESULTS AND DISCUSSION}

The objectives of this study are (i) to identify the level of perception towards radio stations provided by RTM, (ii) to explore the connections of these factors toward understanding the level of listeners' perception towards RTM Radio Station, and (iii) to discover the factor that imposed the highest influence. The findings elaborated are based on these objectives. According to Sekaran and Bougie (2010), the proposed hypotheses that are significant can be proven by analyzing the data that has been collected statistically. Data exploration generates charts and descriptive statistics in which frequency and percentage are calculated to illustrate the distribution of respondents for each demographic variables and factors. To validate the items used to measure each factor and uncover the relationships between the variables, the following methods were used: (i) Cronbach's Alpha Test - to measure the reliability, (ii) 
Normality Test, (iii) Descriptive and Frequency Analyses tools - such as getting the mean, standard deviation (iv) Independent T-test to test comparison and (v) Coefficient to test.

The reliability results remain consistent when the questionnaire was administered in the actual survey. Cronbach's alpha values for all items are more than 0.7 . The distribution of each factor is examined to ensure the normality assumption is met; this is a requirement to establish a valid interpretation of the parametric tests like mean and correlation tests. Table 2 shows the results of normality checking using descriptive measures of skewness and kurtosis. All factors are assumed to have normality as the criteria on skewness and kurtosis values are met, i.e., skewness +/- 2.0 and kurtosis +/- 2.0 (George \& Mallery, 2010) or less stringent criteria of skewness $+/-3.0$ and kurtosis + /- 10.0 for social science research (Kline, 2005).

Table 2: Test of Normality

\begin{tabular}{ccc}
\hline Factors & Skewness & Kurtosis \\
\hline Perception & -0.377 & 2.336 \\
Expectation & -0.909 & 3.918 \\
DJ's Criteria & -1.522 & 5.833 \\
Radio Content & -1.242 & 5.030 \\
Songs & -0.610 & 0.921 \\
Promotion & -0.816 & 3.592 \\
\hline
\end{tabular}

A total of 130 respondents are recruited in this study and is comprised of equal sizes of both genders, dominated (47.7\%) by younger age group (20-29 years old), largely Malays (76.2\%), about $40.3 \%$ having highest education level of up to secondary school, and most of them work in the government sector $(41.5 \%)$. The breakdown of the profile distribution is shown in Table 3.

Table 3: The Respondents' Demographic Profile

\begin{tabular}{lcc}
\hline \multicolumn{1}{c}{ Profile } & Frequency & Percentage (\%) \\
\hline Gender & & \\
Male & 65 & $50 \%$ \\
Female & 65 & $50 \%$ \\
Age & & \\
$20-29$ & 62 & 47.7 \\
$30-39$ & 29 & 22.3 \\
$40-49$ & 17 & 13.1 \\
50 above & 22 & 16.9 \\
Race & & \\
Malay & 99 & 76.2 \\
Chinese & 11 & 8.5 \\
Indian & 8 & 6.2 \\
Others & 12 & 9.2 \\
Education Level & & \\
Primary School & 2 & 1.5 \\
Secondary School & 55 & 42.3 \\
Diploma & 37 & 28.5 \\
Degree & 28 & 21.5 \\
Masters & 7 & 5.4 \\
PhD & 1 & 0.8 \\
Occupation & & \\
Government Sector & 54 & 41.5 \\
\hline
\end{tabular}




\begin{tabular}{lcc}
\hline Private Sector & 29 & 22.3 \\
Retired & 6 & 4.6 \\
Businessmen & 12 & 9.2 \\
Students & 25 & 19.2 \\
Unemployed/Housewives & 4 & 3.1 \\
\hline
\end{tabular}

The subsequent discussions focus on describing the level of expectation and perception of RTM radio stations. A bar chart of the mean items is used to graphically depicts the levels. Figure 1 shows the expectation rating on each item. The highest level is rated on "The radio station should always deliver the latest information", while the lowest is "Radio stations need to feature celebrities as guest invitations more often for more interesting/entertaining". The overall level of expectation is quite high, with an average of 4.0. The high level of expectation indicates that the audience expectation behaviour is typical. Breaking down into high/low categories of expectation, the means are 4.22 and 3.28. The low expectation group is dominantly comprised of female (33.8\%), 20-29 years $(41.9 \%)$, Chinese $(81.8 \%)$, master's degree (50\%), and students (56\%). While the high expectation group is dominated by the male (69.2\%), 50 years and above $(81.8 \%)$, Malay $(84.1 \%)$, secondary school education level (70.9\%), and pensioners (100\%).

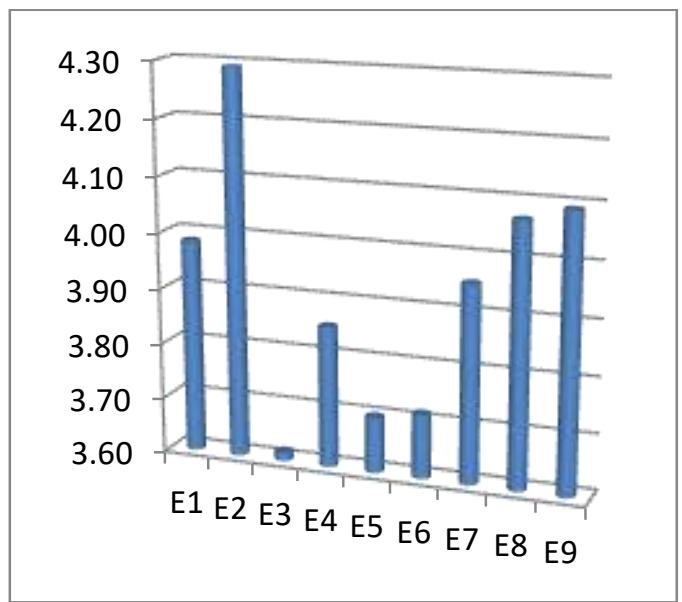

Figure 1: Levels of Expectation (Individual Item)

Figure 2 shows the perception level of each item. The highest is "The RTM radio station uses the good language", and the lowest is "For me, RTM is a radio station that only delivers government information". The overall level of perception is moderate at 3.71 average. This indicates the respondents' perception is at a moderate level. Breaking the respondents into high/low perception, the means are 4.03 and 3.09. The high perception group is dominated by the male $(75.4 \%), 50$ years and older $(72.7 \%)$, Malay $(72.7 \%)$, diploma level of education $(70.3 \%)$, and working in the government sector $(66 / 7 \%)$. While the low perception group is mostly female (41.5\%), 20-29 years old (35.5\%), Chinese (63.6\%), degree level of education (35.7\%), and working in the private sector (41.4\%). 


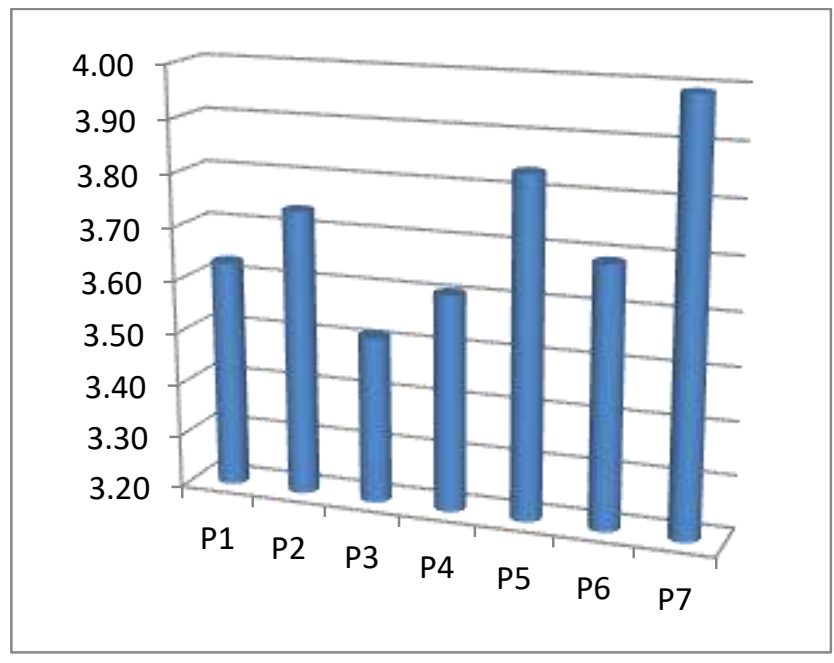

Figure 2: Levels of Perception (Individual Item)

The factors or strategies employed for radio programs are DJ's Criteria, Radio Content, Songs, and Promotion. On the whole, it is reported that the level of each factor is as tabulated in Figure 3, the size of the average levels in descending order are DJ, Promotion, Songs, and Content. When the respondents classified into high/low based on all four factors, yields the following profiles:

Low 4-Factors: Female, 20-29 years, Chinese, Secondary School, Private Sector. High 4-Factors: Male, 30-39 years, Malay, Diploma, Government Sector.

Those in the low values of all four factors ie., low level of positive perception towards RTM Radio Station, are mainly younger Chinese female listeners, completed secondary school and work in private sectors. While those in the high values of all four factors, which indicate positive perception towards RTM Radio Station, are dominantly 30-39-years-old Malay male listeners, completed diploma and work in government sectors.

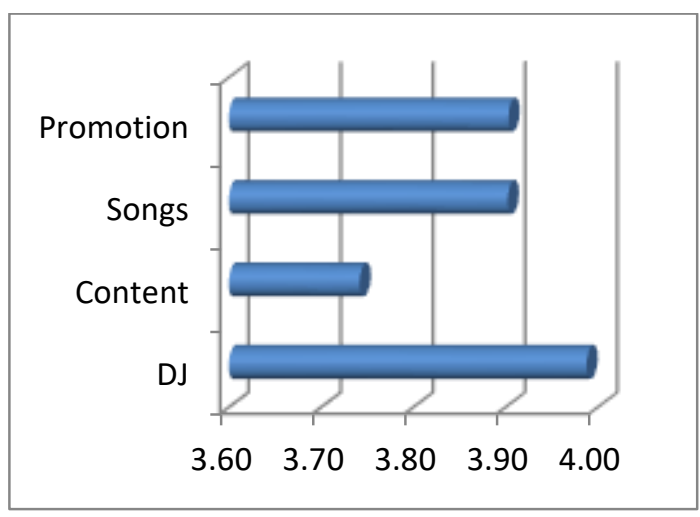

Figure 3: Levels of Perception (Individual Item)

To identify the factors influencing the perception towards radio stations provided by RTM, a cause and effect analysis is conducted. The dependent variable is perception, while the factors or the independent variables are DJ, Content, Song, Promotion, and respondents' demographics such as gender, age group, level of education, race, and working sector/status. Preceding the causal modelling, a correlation analysis is conducted on all numeric variables. 
Table 3 shows the results of correlation analysis between the factors and perception. Out of the four factors, the DJ's criteria exhibit the strongest correlation with perception. Specifically, DJ's Criteria is moderately correlated with Perception, while the correlations of other factors tend to be weak.

\begin{tabular}{cc} 
Table 3: Pearson Correlation Coefficient between & Factors with Perception \\
\hline Factor & $\mathbf{R}$ \\
\hline DJ's Criteria & .591 \\
Radio Content & .459 \\
Songs & .318 \\
Promotion & .488 \\
\hline
\end{tabular}

Stepwise regression is used to estimate a cause and effect model to link the factors and the dependent variable, perception. This technique deployed to elicit (Sekaran \& Bougie, 2010 ) only the significant factors (at $\alpha=0.05$ ) that imposed a causal impact on perception. Diagnostics analysis on the residuals yields confirming results that all assumptions strict on the residuals are met (refer to Figure 4).

The results as shown in Figure 5, yield no lack-of-fit model, with R-square of 0.471 and the estimated function as Perception $=1.029+0.45 \mathrm{DJ}+0.213$ Content +0.298 Male -0.232 Private Sector, which concludes only two factors and two demographics are significant at $5 \%$ level of significance. The explanatory power of the model is low, with only $47.1 \%$ variation in Perception is explained by the model. Two factors, DJ, and Content are significant in influencing (in the positive direction) the level of Perception, with DJ imposing greater impact (0.45) compared to Content (0.213). The level of Perception moves toward a positive direction when the respondents are Male, however in the reverse direction when the respondents are from Private Sectors.

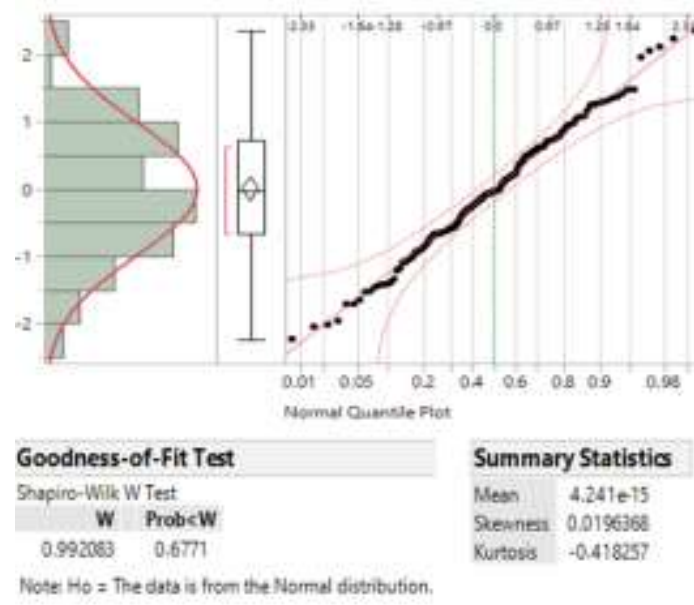

Note $\mathrm{Ho}_{0}=$ The dats is from the Normal distribution.
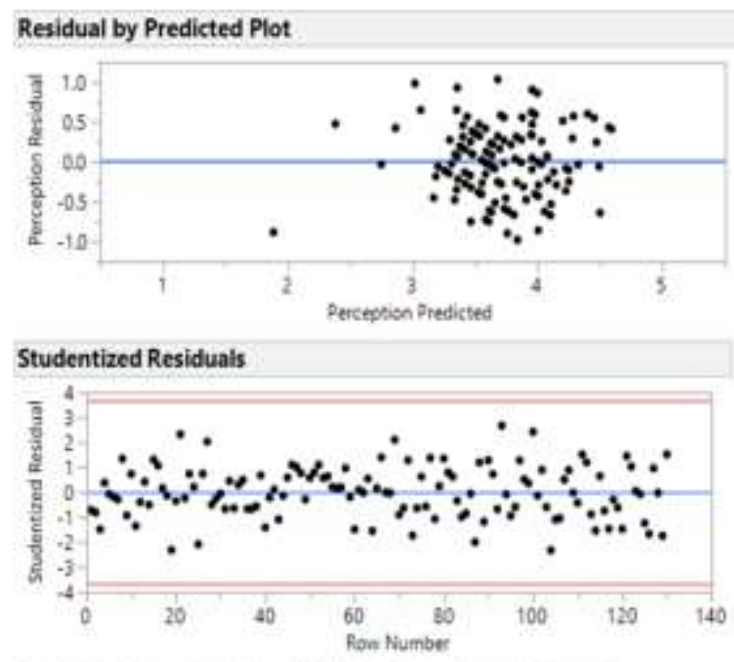

Entemaly Studentized Residuals with 95\% Simuitaneous Limits (Bonferreni)

Figure 4: Residual Diagnostics Analysis 

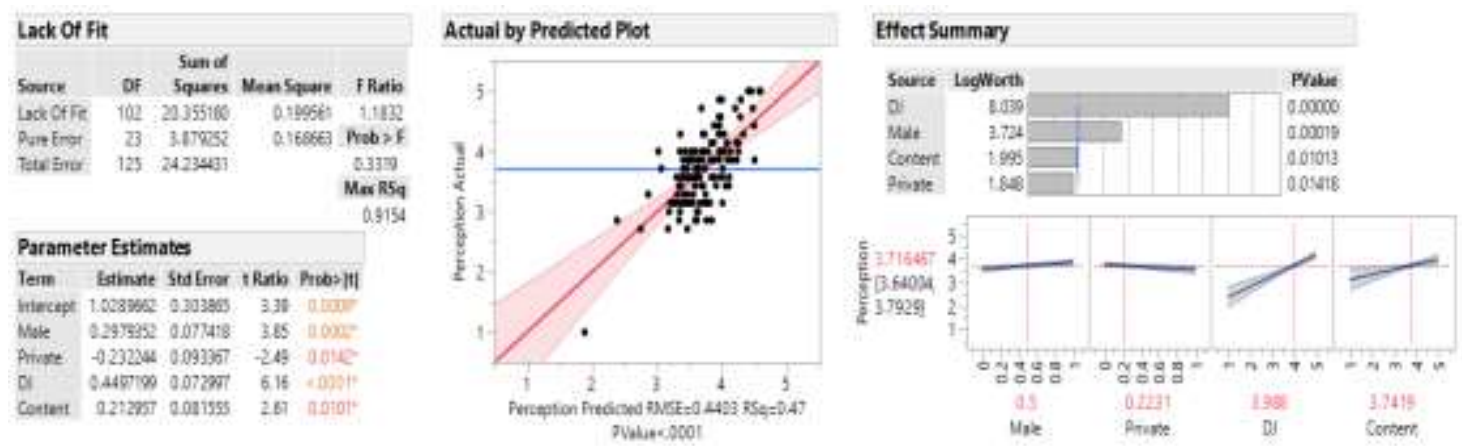

Figure 5: Least Square Regression Model Estimation

\section{CONCLUSION}

As a conclusion, this study has identified the contributing factors to the effectiveness of RTM radio stations to improving RTM in becoming the more preferred and favourable radio station for listeners. From the data analysis and the statistical report, it was found that there is a positive relationship between the variables towards radio listeners. It is no doubt that TVs and radios are mediums that provide information and entertainment to the people in general. Without TVs and radios, the attempts to create an informative human being would not have been possible. Therefore, the role of mass media as a disseminator of information and extensive information is important so that people receive and then think rationally about such information. The highest level is rated on "The radio station should always deliver the latest information", while the lowest is "Radio stations need to feature celebrities as guest invitations more often for more interesting/entertaining" - perception level on each item. The highest is "The RTM radio station uses the good language", and the lowest is "For me, RTM is a radio station that only delivers government information". Two factors, DJ, and Content are significant in influencing (in the positive direction) the level of Perception, with DJ imposing greater impact (0.45) compared to Content (0.213). As communication skills are a DJ best asset, a good DJ can become the ambassador for the radio station he works with.

Therefore, the recommendation from the researcher's point of view is to give effective training for DJs for skills in different areas, including entertainment and information dissemination. Another recommendation is to hire DJs from among celebrities who are popular to attract more listeners. Celebrities are not only singers or actors, but they are also motivators and role models. Thus, RTM should grab the opportunity to attract their listeners using celebrities. Not only that, but DJs should also be extensively promoted because RTM DJs are not as famous as those from other radio stations that promote their DJs very frequently. The promotion of the DJs can be a form of motivation that encourages them to become the best DJs, among others. This is also one of the rewards for them to make the radio station appreciate their talents. Apart from that, the criteria for someone to be a DJ should be considered. The presentation should be more creative, energetic, competent, attractive, and intelligent when they talk to appeal to the target listeners, whether young or old, a housewife or a teenager, and also others. DJs who are young, educated and have a positive attitude should be given priority, and they should always be exposed to the appropriate training. DJs should not change to different fields. They should be given a boost to create a distinctive image. 
Such a radio station can have greater content that is always current, entertaining, very personal as it touches the interest of individual listeners, very informative and cultured. In order to be blessed with these attributes, a radio station must keep in-depth and abreast with the listeners' interest and needs. The radio station must engage in activities that allow it to understand the aspirations of their listeners. What the listeners desire now may not still be in the future. On the other hand, radio content should have a focus in terms of the segmentation of the radio programs. The morning show is one of the more interesting segments. During the morning show, content should relate to the listeners and humour from the DJs, as well as a friendly rapport between them and the listeners are also important. The listeners love to listen to topics that are currently trending and relatable. Meanwhile, it can be more interesting if the topic not too serious, but open for all listeners to share their experiences and ideas.

As a conclusion, the results from this study to identify the factors that contribute to the effectiveness of RTM radio stations will help improve RTM in becoming the more preferred and favourable radio station for listeners. From the data analysis and the statistical report, it was found that there is a positive relationship between the variables towards radio listeners. The recommendations have also been suggested in this report to ensure that there will be more similar studies conducted in the future to improve the current research and to add more findings in the academic fields.

\section{ACKNOWLEDGMENT}

The authors gratefully acknowledge the financial support received from Research Management Institute (RMI) and Faculty of Communication and Media Studies, Universiti Teknologi MARA, Shah Alam, Selangor, Malaysia. The authors would also wish to thank Mardhiyah Binti Mohamed Zin providing data for this research study.

BIODATA

Prof. Dr. Mokhtar Muhammad is a professor at Universiti Teknologi Mara, Malaysia. Email: mokhtar413@uitm.edu.my

Haliza Hasan is a senior lecturer at Universiti Teknologi Mara, Malaysia. Email: haliza018@uitm.edu.my

Aeyneda Zairyn Abdul Jalil is a senior lecturer at Universiti Teknologi Mara, Malaysia. Email: aeyneda@uitm.edu.my

Nur Aziemah Mohd Azman is a senior lecturer at Universiti Teknologi Mara, Malaysia. Email: nuraziemah2753@uitm.edu.my

Raja Putri Nadiah Raja Ahmad is a senior lecturer at Universiti Teknologi Mara, Malaysia. Email: putri2245@uitm.edu.my

Mardhiyah Binti Mohammed Zin is a Program Producer at RTM, Jabatan Penyiaran Malaysia. Email: mardhiyahzin@gmail.com 


\section{REFERENCES}

Abdullah Sulong, \& Mawaddah Abdullah. (2011). Pengaruh media elektronik terhadap keruntuhan akhlak pelajar. Selangor: Universiti Teknologi Malaysia.

Ahlam Abdul Aziz, Jusang Bolong, Md Salleh Hj. Hassan, \& Hamisah Hassan. (2015). Usage of social media to enhance job performance and reduce stress in organisation. Social and Management Research Journal, 12(1), 38-49.

Anderson, M. H. (1984). Madison avenue in Asia: Politics and transnational advertising. New Jersey: Associated University Press.

Asiah Sarji. (1984). The era of wireless in Malaya (Unpublished manuscript).

Asiah Sarji. (1987). Sejarah perkembangan penyiaran di Malaysia (History of broadcasting development in Malaysia) (Unpublished manuscript).

Asiah Sarji. (1994). Pengarah persekitaran politik dan sosial budaya dalam perkembangan penyiaran radio di Malaysia dari tahun 1920-1959. Bangi: Universiti Kebangsaan Malaysia.

Audience Research, Rediffusion. (1983, August-September). Kuala Lumpur: Datasearch Management Sdn. Bhd.

Aziz Muhammed, \& Zainie Rahmat. (1974). Folk songs and folk tradition as an agent of change employed by the ministry of information in disseminating government policies. Presented at John A. Lent's Comparative Media Systems course, Universiti Sains Malaysia, Jan. 1974.

Babbie, E. (2010). The practice of social research. Belmont, CA: Wadsworth.

Berita RTM. (2016, June 30). Malaysia ke arah pendigitalan sistem penyiaran televisyen bermula-2018.

George, D., \& Mallery, M. (2010). SPSS for windows step by step: A simple guide and reference (17.0 update, 10 ed.). Boston: Pearson.

Hasrul Hashim, \& Bahiyah Omar. (2011). Transformasi penyiaran televisyen melalui internet: Kajian perhubungan kepuasan terhadap pengguna remaja. Jurnal Komunikasi: Malaysian Journal of Communication, 27(1).

Intan Soliha Ibrahim, \& Juliana Abd Wahab. (2016). Radio development in the Malaysian digital era: A review of the literature. Paper presented at Seoul International Conference of Social Sciences and Management, January 5-7, 2016.

Jack, G., \& Balakrishnan, R. (1978). Malaysia. In, J. A. Lent (Eds.), Broadcasting in Asia and the Pacific. Philadelphia: Temple University Press.

Kaur, K., \& Shaari, H. (2006). Perceptions on the relationship between public relations practitioners and journalist. Kajian Malaysia, XXIV(1\&2), 9-32.

Kementerian Komunikasi dan Multimedia Malaysia. (2017, Mar 7). Datuk Jailani Johari - RTM siaran digital.

Kementerian Komunikasi dan Multimedia Malaysia. (2019, April 1). Sambutan Hari RTM Ke73 Auditorium Perdana, Angkasapuri.

Lent, J. A. (1978, March). Malaysia's national language mass media: History and present status (Notes). South East Asian Studies, 15(4), 598-612. Retrieved from http://hdl.handle.net/2433/55900

Lent, J. A. (1978). Malaysia's national language mass media: History and present status. South East Asian Studies, 15(4).

Malay Mail. (1921, July 30). 
Malhotra, N. K. (2009). Basic marketing research: A decision-making approach. New Jersey: Pearson Prentice Hall.

Mathews, M. (1973). A history of broadcasting in Malaysia. Presented at John A. Lent's Journalism II course, Universiti Sains Malaysia.

McCombs, M. (2005). A Look at agenda-setting: Past, present and future. Journalism Studies, 6(4), 543-557. https://doi.org/10.1080/14616700500250438

McCombs, M. (2018). Setting the agenda: Mass media and public opinion. Hoboken, NJ: John Wiley \& Sons.

Mohammad Hamdan Adnan. (1985). The mass media in Malaysia. Media Asia, 12(1), 161-169.

Mohd. Naim Ismail. (1974). Suara Malaysia (The voice of Malaysia). Presented at John A. Lent's International Communication course, Universiti Sains Malaysia, Jan. 1971.

Neuman, W. L. (2011). Social research methods: Qualitative and quantitative approaches. Wisconsin: Whitewater.

Robbins, S. (2001). Organizational behavior (9th Ed.). New Jersey: Prentice Hall Inc.

RTM. (2014). Kajian maklum balas pendengar terhadap Radio Nasional FM 2014. Angkasapuri, Kuala Lumpur.

RTM. (2015). Kajian maklum balas pendengar terhadap Radio Nasional FM 2015. Angkasapuri, Kuala Lumpur.

Santokh, T. K. (1979). Broadcast development in Malaysia: Communal structures and national aspirations (Doctoral dissertation: 40, 2963A, Northwestern University, 1979).

Sekaran, U., \& Bougie, R. (2010). Research methods for business: A skill building approach. New York: John Wiley and Sons.

Shin, H. C. (2009). The influence of media frames on the public's perception of biofuel. Ames, US: Iowa State University.

Steven, S. W. (2004). Television via internet: New direction. Journal of Broadcasting \& Electronic Media, 48(3), 513-517.

The Star. (2015, Oct 10). RTM digitization process completed 2017.

Thoha, M. (1998). Perilaku organisasi konsep dasar dan aplikasinya. Jakarta: PT. Raja Grafindo Persada.

Utusan Malaysia. (2015, Apr 8). Sistem TV digital sepenuhnya pada 2020.

Utusan Malaysia. (2016, Oct 10). RTM beralih kepada siaran televisyen digital pada 2018.

Valkenburg, M. P., \& Soeters, K. E. (2001). Children's positive and negative experiences with the internet: An exploratory survey. Communication Research, 28(5), 652-675.

Ziad, I. A. (2006). Impact of information and communication technology on teaching and training (Dissertation PhD, College of Communication, Ohio University, US). 


\section{APPENDIX 1}

E1

Listen to a radio station that plays a favorite song of the listener The radio station should always deliver the latest information Radio stations need to feature celebrities as guest invitations more often for more interesting/entertaining Listen to highly interactive radio stations with listeners Radio stations need to have lots of quizzes/competitions so that listeners can take part Listen to radio stations that can feel like friends are talking together Listen to radio stations that give listeners ideas / advice / tips Listening to radio stations that always provide information on traffic and weather reports especially during driving in the morning and evening Listening to radio stations that discuss interesting and up-to-date topics

For me, the ranking of radio stations is important

For me, RTM is an overly formal radio station

For me, RTM is a radio station that only delivers government information

For me, the information provided by the RTM radio station is comprehensive

Radio station RTM is not like private radio

I chose the RTM radio station because the news was authentic

The RTM radio station uses good language and does not rub

Good interactions between DJ and listeners are important

DJ should have a nice and pleasant attitude both for themselves and for others (sense of humor)

The style of presentation and conversation $\mathrm{Dj}$ influences the listener

DJ amongst celebrities are preferred by listeners

DJ needs to be active in social media and on-site events

DJ that controls a segment should be appropriate in order to communicate something well

DJ is on duty at the same time (morning/ evening/night)

DJ needs to be informed

DJ in pairs are more powerful than solo

The current issues broadcast on the radio are preferred by listeners

Competitions/quizzes organized by radio stations will attract a large number of listeners

Latest songs and trends played by radio stations will attract more listeners

Short topics are preferred over long topics

Radio stations need to have programs that can promote products or goods

The content or topic of the radio being discussed should be favored by the listener

Advertising on the radio is important for listeners

Entertainment needs more information

The concept of radio stations should be different from their competitors

Ask songs from DJ talking

The latest song needs to be played

Songs posted by the listener (song chart)

Features a segment that allows listeners to make interactive choices

Various categories of songs (classic, pop, R \& B, Dangdut, Hollywood, Bollywood, and others)

Songs in the morning and evening need to be more vibrant

Publish folk or regional songs 
S8 Avoid repeating songs over a day

S9 The title of the song is announced on before and after the broadcast

Pr1 Event sponsorships are the most effective way to promote radio stations

Pr2 Charitable programs will create good publicity for radio stations

Pr3 On-site events are the most effective way to promote radio stations

Pr4 Suggestions from friends have a strong influence on the selection of radio stations among listeners Radio stations need to be in good cooperation with the media so that the station is easy to get

Pr5 publicity

Pr6 Promotion of station radio needs to use TV broadcasts

Printed advertisements (billboards, newspapers, and magazines) are effective for promoting radio

Pr7 stations

Pr8 Station radio needs troopers that will drop off at the location to be more recognizable

Pr9 Social media needs to be constantly updated 